\title{
Assessing Prospective Teachers' Affective Component Related to Working with Statistical Projects
}

\author{
María M. Gea ${ }^{a}$ \\ Assumpta Estrada $\odot^{b}$ \\ Carmen Batanero@ \\ ${ }^{a}$ Universidad de Granada en el Departamento de Didáctica de la Matemática, Campus de Cartuja, Granada, Granada, \\ España. \\ ${ }^{\mathrm{b}}$ Universidad de Lleida, Facultad de Educación, Lleida, Lleida, España. \\ Received for publication on 16 Apr. 2019. Accepted, after revision, on 29 May 2019. \\ Assigned editor: Claudia Lisete Oliveira Groenwald.
}

\begin{abstract}
The aim of this paper was to evaluate the cognitive component of Spanish prospective high school teachers about correlation and regression. The evaluation is based on the analysis of the cognitive suitability of a statistical project carried out by 65 students preparing to become mathematics teachers, after having previously worked with that project. The project is based on real data from the relationships of live expectancy with different indicators of human development, taken from the UN web server, and is intended to introduce correlation and regression in high school, The analysis of the participants' written productions is used to assign a level in each indicator of cognitive suitability, which extends those proposed in a previous work. It also serves to identify examples of the cognitive component of teachers' knowledge about correlation and regression.

Keywords: Didactic-mathematical knowledge, cognitive component, correlation and regression, assessment.

\section{Evaluación de la Componente Afectiva del Trabajo con Proyectos Estadísticos por Futuros Profesores}

\section{RESUMEN}

El objetivo de este trabajo fue evaluar la componente afectiva del conocimiento didácticomatemático sobre la correlación y regresión de los futuros profesores de Educación Secundaria Obligatoria y Bachillerato españoles. La evaluación se realiza a partir del análisis que una muestra de 65 estudiantes que se preparan como profesores de matemáticas realizan de la idoneidad cognitiva de un proyecto estadístico, después de haber trabajado previamente con dicho proyecto. El proyecto está basado en datos reales sobre la relación de la esperanza de vida con diferentes indicadores del desarrollo humano, tomados del servidor de las Naciones Unidas y fue pensado para introducir las ideas de regresión y correlación en Bachillerato. El análisis de las producciones escritas de los participantes permite asignarles un nivel en cada uno de los indicadores de la idoneidad afectiva,
\end{abstract}

Corresponding author: María M. Gea. E-mail: mmgea@ugr.es

\begin{tabular}{|l|l|l|l|l|l|}
\hline Acta Scientiae & Canoas & Vol. 21 & N. 3 & p.112-130 & July/Aug. 2019 \\
\hline
\end{tabular}


que extienden los propuestos en un trabajo previo. También permite mostrar ejemplos de la componente afectiva del conocimiento didáctico-matemático de los futuros profesores sobre la correlación y regresión.

Palabras-clave: Conocimiento didáctico-matemático, componente cognitiva, correlación y regresión, evaluación.

\section{INTRODUCTION}

The teaching of statistics in secondary education is today widespread, due to the need to equip citizens with reasoning strategies that allow them to face decisions in the information society. We also observe the growing tendency to introduce the work with statistical projects, which allow students to better understand the usefulness of statistics as research instrument. Thus, the GAISE report (Franklin, et al., 2007) suggests that in project work, students can design research, formulate research questions, collect data to answer these questions, analyse the data and obtain some conclusions about the initial questions or predictions, which are supported by data analysis results.

An effective teaching of statistics based on project work requires attending the education of teachers, as some may feel insecure when teaching the topic (Pierce \& Chick, 2011), if they did not received enough didactic support along their period of education. Souza, Lopes, and Pfannkuch (2015) indicate that teachers may not be aware of the possibilities that statistical projects offer or the way they can be used to make sense of reality; therefore it is important to immerse teachers in a reasoning and learning environment centred on this type of work.

Moreover, a current purpose of statistical education is making teachers to pay attention to the affective aspects related to statistics, given their impact on learning (Tishkovskaya \& Lancaster 2012) and the fact that teachers can transmit their own attitudes or beliefs to the students (Estrada, Batanero \& Lancaster, 2011).

Consequently, in this research we are interested in the degree to which prospective secondary education teachers are able to assess the affective aspects related to working with statistical projects. Such competence is part of the affective component of teacher knowledge, according to Godino (2013). In the following sections, we describe the study background and methodology, analyse the results and discuss the implications for teacher education.

\section{THEORETICAL FRAMEWORK}

We base our research on studies on affectivity in mathematics, as well as on the affective component of the teacher's didactic-mathematical knowledge model, which are summarized below. 


\section{Affective Domain in Statistics}

The affective domain strongly influences the learning of mathematics, as it is evidenced by related research, such as, for example, Gómez-Chacón, 2000 or Blanco, Guerrero and Caballero (2013). Its importance is explained by its possible influence on the cognitive processes related to mathematical thinking, such as, for example, creativity, visualization, intuition or argumentation (Gómez-Chacón, 2016). There is an additional cyclical relationship between the affective dimension and learning, since the students' experience in learning mathematics affects their emotions and beliefs that, in turn, have a strong influence on their ability to learn (Gil, Blanco \& Guerrero, 2005).

Within this domain, Phillip (2007) distinguishes between emotions, attitudes and beliefs, which differ in the stability of the affective response they represent, the degree to which cognition intervenes in their formation, as well as in the time they take to develop.

Students 'emotions about mathematics include feelings such as liking/disliking, fear or interest (Gómez-Chacón, 2000), and are formed over time, as the students react to their experience during the learning of the specific topic. Hannula (2002) distinguishes between the emotions linked to a particular stimulus (e.g., an examination, or solving a problem), those associated with particular consequences, and personal values.

Philipp (2007) considers attitudes as ways of acting, feeling or thinking that reveal a person's disposition towards the topic, while Kilensko (2009) considers them as affective responses that can be positive or negative, are stable, and moderately strong. Di Martino and Zan (2015) suggest that attitudes constitute a bridge between beliefs and emotions and their mutual relationships. They can influence the person's behaviour with respect to the topic and his/her willingness to continue studying or using what they learnt in the classroom (Veloo \& Chairhany, 2013).

There are varied beliefs about a subject, which can refer to the topic itself (for example, consider the theme to be easy or difficult), or to the person's relationship to the matter (e.g. confidence or self-concept). Among the beliefs that influence the motivation towards the topic Goldin et al. (2016) include interests and preferences, perception of the instrumental nature of the topic, as well as its relationship with the students' close or long-term objectives. All these beliefs are reinforced in a positive way, for the case of statistics, through project work.

According to Estrada, Batanero and Lancaster (2011), attitudes and beliefs towards statistics, develop slowly, because of positive or negative experiences in learning the subject and are difficult to change. Consequently, it is important that teachers are able to identify the affective aspects related to their teaching or the students' work in the classroom; hence, the interest of the analysis of teacher's knowledge affective component. 


\section{Affective Component in Teacher Knowledge}

A wide research is focused on the different components of teacher's knowledge to teach mathematics (for example, Dawson, Jaworski \& Wood, 2013, Hill, Ball, \& Schilling, 2008 or Llinares, 2018). In this paper, we rely on the model of teachers' mathematical didactic knowledge (MDK) proposed by Godino and collaborators (Godino, Giacomone, Batanero \& Font, 2017, Pino-Fan \& Godino, 2015).

This model characterizes the teacher's knowledge from the mathematical dimension, the didactic dimension and the meta-mathematical dimension. In the didactic dimension of MDK, which is our centre of interest, six facets are taken into account (Pino-Fan, Godino, 2015):

1. Epistemic facet or specialized knowledge of the mathematics that the teacher has to teach. It is the didactic-mathematical knowledge about the content itself, that is, the particular way in which the mathematics teacher understands and knows mathematics. According to Godino et al., 2017), this facet is not limited to the conceptual and procedural components, which are considered in other theoretical frameworks, but also takes into account the fields of problems addressed, language and argumentation.

2. Cognitive facet or knowledge about the cognitive aspects of students, related to their learning and understanding of the subject, the way they reason or solve mathematical problems, as well as their difficulties.

3. Affective facet or knowledge of the affective, emotional and attitudinal aspects in relation to the content. Any activity proposed to the students does not only involve some mathematical knowledge, but also mobilizes some beliefs, values or attitudes in these students, which undoubtedly influence their learning and the future application of what they have learnt. Affective suitability suggests that the interest and motivation of students was achieved throughout the study process, both in relation to the particular theme, as well as for succeeding in solving the proposed activities.

4. Interactional facet or knowledge of the interactions arising in the classroom, and the way they promote interaction that help identifying and solving the students' difficulties.

5. Mediational facet or knowledge of educational resources, materials, textbooks, and technology that can help improve student understanding.

6. Ecological facet, which includes the curriculum, relationship with other subjects and social, political, economic factors that affect the management of student learning.

Each of these facets is related to the corresponding component of didactic suitability (Godino, 2013, Godino: Rivas, Arteaga, Lasa, \& Wilhelmi, 2014), which the authors introduce to design or evaluate the learning and teaching of mathematics. The theory 
of didactic suitability has been widely used in educational research to evaluate didactic programs, and the learning and teaching of mathematics, through its various components (for example, in Arteaga, Batanero \& Gea, 2017, Beltrán-Pellicer \& Godino, 2017). According to Godino et al. (2017), the evaluation of didactic suitability contributes to reflection and to the progressive improvement of teaching practice ; for this reason it has been used as a training practice for teachers in Latin America (see Breda, Font, \& Lima, 2015).

Specifically in this research we are interested in the affective suitability of a statistical project aimed at secondary education students. This affective suitability measures the degree to which the aforementioned project can contribute to improving the students' interests, emotions and attitudes regarding statistics and the competence to evaluate affective suitability are part of the affective facet of the teacher's knowledge. According to Godino (2013), affective suitability is related both to institutional factors, and to factors depending of students and their previous school history. When analysing the affective suitability, prospective teachers should take into account their own degree of involvement, interest and motivation in relation to the development of the statistical project.

The most direct antecedent of our work is that by Arteaga, Contreras, Cañadas and Gea (2017) who asked 108 prospective primary education teachers to evaluate the emotional suitability of a simple statistical project, after having worked with it, and using the components and indicators proposed by Godino (2013). The authors assigned each teacher a score of 0 to 3 on each indicator, taking into account the response correctness and completeness Their results were poor, because less than $50 \%$ of the participants managed to reach the maximum level 3, when analysing the interest of the study of statistics and only between 6 and $35 \%$ of them reached the maximum level in the remaining indicators. The most difficult task was applying the indicators of emotions, particularly those related to the aesthetic and precision of mathematics.

In this paper we use the same methodology, in extending the score assigned to each response to a 0 to 5 scale. Since we work with prospective secondary school teachers, a more advanced statistical project different from that used by Arteaga et al. (2017) will be used. In this way, we continue a previous work (Gea, Batanero, Arteaga, \& Estepa 2019) in which, we analyse the cognitive component of teacher's knowledge about correlation and regression with the same methodology and sample.

\section{METHODOLOGY}

\section{Sample and Context}

The study was developed with 65 students who were training as prospective mathematics teachers, within the Master's Degree in Secondary Education and High School, which is compulsory in Spain for those who wish to pursue a teaching career. Only $56 \%$ of participants had a Batchelor in Mathematics or Statistics and the remaining 
had studied engineering, architecture or other science careers. All of them had completed one or more statistics courses and $57 \%$ of participants had some teaching experience. The subjects were split into two groups of approximately the same size, who worked with the same teacher and method.

The evaluation was part of a training workshop, which was developed over three sessions of two hours each within a Mathematics Teaching Innovation course. During the first two sessions, the participants worked with a statistical project and in the third, the study of the didactic suitability of the project was carried out.

\section{Data Analysis Project}

The statistical project given to participants to work with along the first two sessions revolved around the question: What are the factors that most influence a country life expectancy at birth? which served to propose different tasks related to correlation and regression. The project data was taken from the United Nations Development Reports data, which are available on the server (http://hdr.undp.org/en/data). More details about the project are given in Batanero, Gea, Díaz and Cañadas (2014).

The variables used in the project are international indicators of human development and were selected by taking into account the results of previous research on understanding correlation and regression and the factors that affect the students' difficulty (see Estepa, 2008). In addition to linear regression, different fitting models were used, such as exponentials and polynomials functions that are studied in secondary education. The possibility of observing positive and negative sign and different degrees of correlation was also provided. Moreover, different relationships explaining correlation were used, such as cause and effect, interdependence or indirect dependence. Finally, in some variables the correlation observed in the data contradicted and in others confirmed the participants' previous expectations.

When introducing the project, the teacher educator discussed with the prospective teachers the meaning of the different variables and the way in which the data were collected. The meaning of Life expectancy (dependent variable in the project) was analysed in depth through the interpretation of different graphical representations (histogram, cumulative percentage frequency diagram, and box plots), as well as statistical summaries of its distribution. Once the meaning of the variable was clear, the participants were given the tasks of the workshop; the project data was given to the teachers in an Excel spreadsheet. Once the answers to the task were collected, the solutions were discussed, in order to solve possible difficulties and develop the prospective teachers' statistical knowledge. 


\section{Instrument}

In the third session, devoted to developing the participants' didactic knowledge, the participants analysed the didactic suitability of the project worked in the two previous sessions. In this paper, we only study their analysis of the project affective suitability, which was based on the indicators proposed by Godino (2013) and presented in Table 1. This table contains six indicators, written in the form of questions related to students' interests, attitudes and emotions. The prospective teachers had to respond to each of the indicators (questions). The analysis of affective suitability is a specific task of the teacher's work, which must previously identify the affective aspects of the project being analysed.

Table 1

Guide to analyse affective suitability.

\begin{tabular}{ll}
\hline \multicolumn{1}{c}{ Components } & \multicolumn{1}{c}{ Indicators } \\
\hline Interests and needs & I1. Do you think the tasks are interesting for the students? \\
& I2. Are the students involvement in the activities, their responsibility, etc. promoted? \\
I3. Is student participation promoted in the activities, their responsibility, etc.? \\
I4. Is argumentation favoured in situations of equality? Is the argument valued in itself \\
and not because of the person producing it? \\
I5. Does the project reinforce self-esteem, in helping to avoid rejection, phobia or fear \\
of mathematics? \\
I6. Are the aesthetic qualities of mathematics highlighted? What other positive attitudes \\
or emotions toward mathematics would help the project develop?
\end{tabular}

Once the participants' answers were collected, we carried out a content analysis of these responses (Krippendorff, 2013) and each of them was assigned a level that took into account the knowledge shown in the application of the indicator (level 0 means no answer). These levels develop the three levels proposed by Arteaga et al. (2017) and are the following, for all the indicators:

L1. The question is answered, although the participant just copies the indicator without linking it to the project analysed.

L2. The question is answered and the indicator is applied, but the prospective teacher does not focus on the project, but on anecdotal facets or on aspects that were not strictly affective. We also included into this category those answers in which the teacher correctly applied only a part of the indicator, where another part was incorrect.

L3. The indicator is applied to affective aspects of the project, but the participant focuses on another different indicator.

L4. The indicator is applied correctly, using the contents of the project in a consistent way, and is based on a single example.

L5. The indicator is applied correctly and consistently, and is reasoned through two or more examples. 


\section{RESULTS AND ANALYSIS}

In this section, we present the results, by grouping them into interests and needs, on the one hand and into emotions and attitudes on the other. Firstly, in each indicator, the expected responses are described. Next, examples of the participant's valuations in each of the levels of application of the indicators are presented. Finally, the results for each component are synthesized and discussed.

\section{Interests and Needs}

\section{I1 Do you think the tasks are interesting for the students?}

As a response to this question, we expected that the prospective teachers commented on the interest of the proposed tasks and of working in a project, which is an innovative methodology, when compared to the traditional mathematics lesson. In this sense, project work allows students to work through the different stages of a statistical investigation; as Holmes (1997) suggests, it increases the students' motivation, since the data acquires meaning and has to be interpreted.

Furthermore, the tasks are designed in an international context, with real data, and address a topic of interest in real life. Not only is the analysis of Life expectancy in the different countries that constitute the sample is interesting, but the comparison of the Spanish situation with other countries is also motivating. Especially in the current context, when the economic crisis is being overcome. Throughout the project, different graphical representations of the data were explored, and the prospective teachers were allowed to add other variables of their interest. All these elements increase the students' motivation.

I2. Do the proposed tasks allow valuing the usefulness of mathematics in everyday and professional life? Why?

When working on the project, the prospective teachers have completed the research cycle proposed by Pfannkuch and Wild (2004). Starting with a question, they analyse and interpret some data, and finally they answer the proposed question. This method could be used in other investigations, so the project shows the usefulness of statistics when conducting a research (McGilliwray, \& Pereira-Mendoza, 2011). Moreover, the participants were expected to confirm that data analysis and working with graphic representations is very useful for forming statistically educated citizens (Ridgway, 2015). It is also important in a teaching and research innovation course, like the course that participants were following, as it provides them with a teaching method that they can use with their future students.

Moreover, the teacher insisted throughout all the sessions on the current need for statistical literacy, which is an essential ingredient in a democratic society, as well as for 
professional development. This culture is a consequence of the wide availability of data of social interest and can be increased through the interpretation of the different graphs (Engel, 2019).

Below, we show examples of answers to the two indicators previously analysed at levels L2, L4 and L5, since level 0 is no response, there were no responses at level 3 and level L1 simply consists in transcribing the question given in the indicator.

Level L2, where part of the indicator is applied correctly, while another part is omitted, there is some mistake, or aspects unrelated to the project are used, as we observe in the following examples.

Yes, with mathematics you can collect data and carry out some studies to observe the changes that are required, how and where to make the changes to obtain the results we expect. (PP, indicator I2)

Any task is interesting for the student; it only depends on how we approach the task and the interest that we put into it. (AMC, indicator I1)

Yes, because statistics is used by the media with private and public interests, and reflect daily realities. (CA, indicator $\mathrm{I} 2$ ).

At Level L4 there is a correct and consistent application of the indicator by using a single example. The prospective teachers mainly points out the context of the tasks as the main element of interest for the student, with which the usefulness of mathematics in daily life can be appreciated. Other participants point to project work as a motivating element in itself:

Yes, because they are framed in a real situation. such as the analysis of life expectancy. (AJD, indicator I2)

Yes, because it allows objectively verify or reject strong relationships between social variables, which the student intuitively suspects are related. (MAG, indicator I2) I think it should be an interesting task for them. because they work with a project and this gives the students some freedom. (ATL, indicator I1)

At Level L5 there is a correct and consistent application of the indicator, through two or more examples. We find answers from prospective teachers at this level, especially regarding the indicator L2. Again, they refer to the interest of the context, which can be analysed from a comparative perspective (AJD), or the importance of mathematization (PJ):

Yes, because it is outstanding and motivating to work with real data; in addition to being able to place your country with respect to others, which is interesting. (AJD; indicator I1) 
Yes, because you can only find an answer to the problem proposed in the project when you mathematize the data provided to us, and you reason with arguments, using the logic laws of statistics to give an objective answer; otherwise we will only have an intuitive and untested idea of the correct solution. (PJ, indicator I2)

In Table 2, we summarize the results obtained in each of the levels described. We can observe a high percentage of answers in levels 4 and 5, that is, those in which the prospective teachers come to justify the tasks interest with one or more examples, correctly applied. In the case of indicator L1, the interest the context has for students stands out ( $82 \%$ of answers in level 4 or 5), and for indicator L2 it is highlighted that project work contributes to valuing the utility of mathematics with different arguments (66.1\% at level 4 or 5$)$.

Table 2

Frequency (and percentage) of levels in the assessment of interests and needs.

\begin{tabular}{ccc}
\hline Level & Indicator I1 & Indicator I2 \\
\hline 1 & $3(4,9)$ & \\
2 & $8(13,1)$ & $14(23)$ \\
4 & $30(49,2)$ & $10(16,4)$ \\
5 & $20(32,8)$ & $37(60,7)$ \\
\hline Total & $61(100)$ & $61(100)$ \\
\hline
\end{tabular}

\section{Attitudes and Emotions}

In this part of the affective component the participants had to assess if the tasks carried out throughout the project are useful to generate positive attitudes and emotions. Two questions were posed to fulfil this aim, which we describe below.

\section{I3. Is student participation promoted in activities, their responsibility, etc.?}

The students had previously solved the project tasks. For this reason, they were left free to choose the method (i.e., graphs, tables or statistical calculations, since the question could be answered using different methods). Thus, the students were responsible for their learning, as it was necessary to integrate and assimilate their solution to the project with those of other colleagues.

On the other hand, as indicated before, participants were allowed to choose new variables to analyse and create new problems. Likewise, as an extension activity, it was requested to search and analyse some didactic resources on the Internet to improve the students' understanding of the project's work concepts, especially correlation and 
regression. Consequently, the future teacher is expected to value the active work of the student and their personal involvement in the study of the topic.

I4. Is argumentation favoured in situations of equality? Is the argument valued in itself and not because of the person producing it?

This question has no relation with the project itself, but with classroom management. Although a part of the project we developed individually, the lecturer organized a phase of correction and collective discussion of the activities, in which the equality of argumentation between the participants was fostered, and a space for the evaluation of the student was developed.

I5. Does the project reinforce self-esteem, in helping to avoid rejection, phobia or fear of mathematics?

Rejection and negative attitudes towards mathematics are frequent, especially when the student has experienced an excessively formal teaching, where there are not enough applications that give meaning to the presented knowledge (Estrada, Batanero \& Lancaster, 2011). Our participants may have perceived this rejection in their teaching experience or when they were students, which is often motivated by negative experiences in failing to solve problems. When the tasks are accessible for the student, and they can solve them, or most part of them easily, the student feels motivated, which helps increase their selfesteem and understand that they are capable of doing mathematics, which is what actually occurred in the development of the project. Therefore, we expected a positive and justified evaluation of this question. In addition, the concepts, properties and procedures used throughout the project were those required to solve the research question; so the student can understand the need for such knowledge, and value the learning of mathematics.

I6. Are the aesthetic qualities of mathematics highlighted? What other positive attitudes or emotions toward mathematics would help the project develop?

Although the aesthetic qualities of mathematics could go unnoticed by the student, these qualities have been highlighted by some mathematicians such as Guzmán (2003), who remark their depth, generality, economy of thought, transparency and visual beauty, in the case of graphic representations. The experience of mathematical creation, which according to Guzmán also produces aesthetic emotions, is shown in the project worked by the students, since the analysis of the data allows discovering hidden patterns, through a process of transnumeration (Pfannkuch \& Wild, 2004). Thus, from the disordered list of data, we move on to the scatter plot (bubble chart or map), from which the mathematical regression model emerges, which expresses both the order of the parts (distribution) and the interrelation between the variables (correlation). The possibility of extracting a trend from the disorder of the data can be seen as an aesthetic quality. 
Other positive emotions, as some of the dispositions that Pfannkuch and Wild (2004) include in statistical thinking, are developed through working with the project. These are curiosity, imagination, open mindedness to new ideas, logical capacity, and commitment to work. It is expected that the future teacher will appreciate the different aesthetic qualities and emotions that are produced with the project.

Below, we show examples of answers in which future teachers apply these indicators in levels L2 to L5.

At level L2, participants refer to attitudes or emotions, and do not focus specifically on the project, or make an incomplete application. For example, the participation of the student is valued (indicator I3), but it is conditioned to the teacher's action in the classroom. Regarding indicator I6, the usefulness of mathematics is valued more than its aesthetic qualities; it is considered that the project helps to become aware of the application of mathematics (I5), but not that it contributes to decrease the phobia towards them:

It depends on how the teacher approaches the activity. (DG, indicator I3)

It will rely upon to a large extent on the teacher's ability to transmit the knowledge to their students, so that they are able to solve the tasks and increase their selfesteem. It is appropriate to combine simple tasks with somewhat more complex problems. (MRA, indicator I5)

Yes, the fitting of a dispersed and disordered cloud of points by using a function shows how mathematics can condense information and simplify it by means of a simple model. It also develops the ability to mathematize. (MAG, indicator I6)

At level L3, the indicator is applied correctly, but referring to other emotional aspects developed in the project and not so much to the specific point discussed. We found a single evaluation at this level corresponding to indicator I3 where the teacher refers to the tasks of the project and not so to the attitude, as requested:

It favours data handling, group work, the creation of graphs, choosing the most appropriate function that best fits the points. (BH, indicator I3)

At level N4, the prospective teacher makes a correct and consistent application of the indicator, describing emotions or attitudes promoted in the project, in consistency with the question, although they reason with a single example. The answers of future teachers at this level refer to the responsibility and participation of students in the project or the need to overcome tasks individually (indicator I3).

Yes, because each student independently has to face the activities. (MC, indicator I3). Yes, doing complementary tasks that have been proposed to get better grades (responsibility). (ChC; indicator I3) 
We also find participants who argue that the project favours equality by using nonsexist language (indicator I4). Others indicate that it helps to present mathematics in an entertaining way and that the use of Excel motivates students to reduce their formality and facilitate calculations (indicator I5).

Yes, because it uses generic language, it does not differentiate between men and women. (MC; indicator I4)

Mathematics is seen as something more fun and entertaining and can help improve the situation with mathematics by decreasing the phobia towards the topic. (CM, indicator I5)

Yes, because using the Excel greatly improves self-esteem. since it is not necessary to do complex calculations, the same program provides us with calculations. (LT; I5)

At level N5, a correct and consistent application of the indicator is made by using two or more examples. The answers of the prospective teachers when evaluating the indicator I6 are generally located at this level, pointing out aspects such as graphic representation, or the satisfaction of the use of correlation to test their intuitions.

\begin{abstract}
Yes, the aesthetic qualities of mathematics are highlighted. It helps establishing the average of a set of data, interpret them graphically and establish a degree of correlation between the data. The colours of the graphics. (ChC; indicator I6)

With the graphic representations, the aesthetics of mathematics could be favoured. I believe that taking on challenges or the desire to improve are attitudes that can be developed with this task, since they are a consequence of the reinforcement of self-esteem. (ATL, indicator I6)
\end{abstract}

We also find evaluations of the rest of the indicators in this level, in quoting the responsibility and individual participation of the student, the treatment of equality in the project, and helping to reduce the phobia towards mathematics.

Yes, participation is promoted, but it is necessary to control that all the members of the group are working. The responsibility can be increased by carrying out the complementary activities. (ME, indicator I3)

This project does not make any discriminatory reference. The data are treated objectively and also, when analysing different countries, interculturality in class can be promoted as it is a cross curricular topic. (PJ, indicator I4)

As it is a project the student progresses from a more basic knowledge to their own reasoning. In this sense, their self-esteem is favoured and can help to reduce the aversion to mathematics. (ATL, indicator I5)

Table 3 presents a summary of the results obtained. We can observe the high rate of non-response, mainly in the assessment of reasoning in situations of equality (indicator 
I4), followed by the project's contribution to self-esteem and eradicator of phobia or fear of mathematics (indicator I5). However, many participants reached levels 4 and 5 in the evaluation of the proposed indicators, especially I3 (the project promotes participation and responsibility) and I6 (aesthetic qualities of mathematics highlighted in the project.

Table 3

Frequency (and percentage) of levels in the assessment of attitudes and emotions.

\begin{tabular}{ccccc}
\hline Level & Indicator I3 & Indicator I4 & Indicator I5 & Indicator I6 \\
\hline $\mathbf{0}$ & & $\mathbf{1 5 ( 2 4 , 6 )}$ & $\mathbf{9 ( 1 4 , 8 )}$ & $\mathbf{4 ( 6 , 6 )}$ \\
\hline 1 & $1(1,6)$ & $1(1,6)$ & & \\
2 & $10(16,4)$ & $18(29,5)$ & $14(23)$ & $16(26,2)$ \\
& $1(1,6)$ & & & $13(21,3)$ \\
5 & $25(41)$ & $13(21,3)$ & $17(27,9)$ & $28(45,9)$ \\
\hline Total & $24(39,3)$ & $14(23)$ & $21(34,4)$ & $61(100)$ \\
\hline
\end{tabular}

\section{Synthesis of Didactic Knowledge in the Affective Facet}

To summarize the results of assessing the affective component of these prospective teachers' knowledge in relation to a statistical project, the average scores obtained in each indicator have been calculated, and are presented in Table 4 and Figure 3. This affective component is part of the knowledge of the content and the student according to Hill, Ball, and Schilling (2008). In general, the average score is higher than the theoretical score (2.5) in the evaluation of practically all the indicators, obtaining a lower score in the indicators related to favouring the students 'equality and self-esteem, where a percentage of students did not respond as they did not perceive these elements when working with the project. The total average score is also higher than the theoretical score, since the first three indicators obtained high scores, and in general all the results were quite better than those obtained in Arteaga (2011).

Table 4

Mean and standard deviations in the indicators of affective suitability.

\begin{tabular}{cccc}
\hline Indicator & Content & Mean & Std. deviation \\
\hline 11 & Interest for the student & 3,9 & 1,1 \\
12 & Usefulness of mathematics & $4,1^{*}$ & 1,2 \\
13 & Students' participation & $4^{*}$ & 1,2 \\
14 & Equality among students & 2,6 & 1,9 \\
15 & Self-esteem; rejection of phobia & 3,3 & 1,8 \\
16 & Aesthetic qualities and positive emotions & 3,7 & 1,6 \\
\hline Total & & 3,6 & 1,6 \\
\hline
\end{tabular}




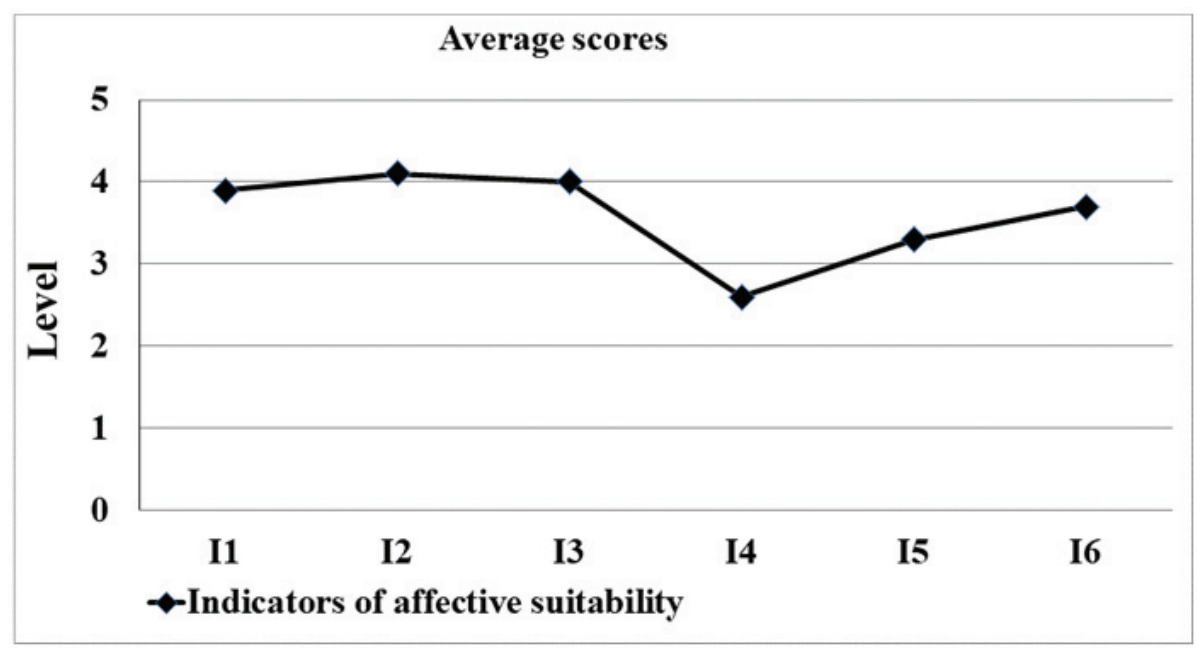

Figure 1. Average score in the assessment of the indicators of affective suitability.

To finish, in Table 5 we include examples of knowledge related to the affective facet, shown in the responses of prospective teachers to these indicators, in levels L4 and L5. As suggested in the curricular guidelines (MECD, 2015), prospective teachers recognize that it is important to present mathematics as a living science, which is part of our culture, and that is useful to interpret reality. They also indicate that the student should be encouraged to have an open and positive disposition towards mathematics, which will be reflected in the dynamics of solving problems that deal with contexts of social relevance, such as the one proposed in the project.

Table 5

Examples of knowledge of future teachers in the affective facet.

\begin{tabular}{|c|c|}
\hline Component & Example of knowledge \\
\hline \multirow[t]{4}{*}{$\begin{array}{l}\text { Interests and } \\
\text { needs }\end{array}$} & $\begin{array}{l}\text { Values the interest of the tasks, because the project gives the student a certain } \\
\text { freedom. }\end{array}$ \\
\hline & $\begin{array}{l}\text { Values the interest of relating data on social variables and being able to compare one's } \\
\text { own country with others. }\end{array}$ \\
\hline & $\begin{array}{l}\text { Recognizes that by using real data on Life expectancy, the project allows the student to } \\
\text { see the usefulness of mathematics. }\end{array}$ \\
\hline & $\begin{array}{l}\text { Values the usefulness of mathematics to provide objective answers to questions of } \\
\text { interest. }\end{array}$ \\
\hline
\end{tabular}

Attitudes Recognizes that independent work within the project promotes students' participation in the activities, as well as their responsibility and initiative.

Notes that argumentation in situations of equality is favoured and that sexism is avoided. 


\begin{tabular}{ll}
\hline Component & \multicolumn{1}{c}{ Example of knowledge } \\
\hline Emotions & $\begin{array}{l}\text { Recognizes that by making mathematics more enjoyable prevents rejection towards } \\
\text { them. } \\
\text { Suggests that working with Excel avoids calculation errors, which increases a positive } \\
\text { attitude. } \\
\text { Recognizes that graphs highlight the aesthetic qualities of mathematics. } \\
\text { Indicates that, as the student progresses throughout the project from basic knowledge to } \\
\text { more advanced reasoning, their self-esteem is favoured. Therefore, it can help reduce } \\
\text { the aversion to mathematics. }\end{array}$ \\
\hline
\end{tabular}

We have found examples of future teachers who have been able to assess the interest of the tasks, the use of real data and technology and the context, as well as the advantages of giving the students autonomy and promoting their responsibility to encourage positive attitudes and emotions towards mathematics.

\section{CONCLUSIONS}

The evaluation of the cognitive component of the didactic-mathematical knowledge by a group of prospective teachers by using their answers in the analysis of the cognitive suitability of a statistical project, previously worked by participants, served to identify, some points where it is necessary to improve this knowledge. In particular, their knowledge about attitudes towards mathematics and its components should be expanded, because its evaluation and the way in which they affect learning, was difficult for part of participants, as well as to evaluate the project's contribution to promote self-esteem or equality among students.

The didactic mechanism implemented for the training of teachers in this subject was adequate, both to motivate these participants and to evaluate and develop different aspects of their didactic-mathematical knowledge. In the first place, the work with the project allowed them to advance in their mathematical knowledge of correlation and regression, and the fact of going through all the stages of a research process to answer a question of interest (What factors influence the life expectancy?) led them to work its mathematical content with interest. The subsequent evaluation of the emotional suitability of the project led to reflection on the different emotional aspects involved in the teaching and learning process of mathematics, which can be improved, as well as the need to become aware of the different types of knowledge that a teacher of mathematics should acquire.

Of course, it would be necessary to complete both the project, in order to adapt it to other statistical contents, as well as the guideline of evaluation used for the affective suitability, taking into account specific beliefs about statistics. This would be a point to bear in mind when continuing with the investigation on the subject.

According to Godino, Batanero, Rivas and Arteaga (2013) in order for teachers to plan didactic processes with high affective suitability, they must be aware of the relevant 
role of the affective dimension in the learning of mathematics. As a consequence, we suggest the need to take into consideration the affective dimension in the formation of the mathematics teacher, developing their competence to create situations that are of interest to students, allow them to see the usefulness of mathematics and promote positive emotions, such as responsibility or self-esteem.

\section{REFERENCES}

Arteaga, P., Batanero, C., \& Gea, M. M. (2017). La componente mediacional del conocimiento didáctico-matemático de futuros profesores sobre estadística: un estudio de evaluación exploratorio. Educação Matemática Debate, 1(1), 54-75.

Arteaga, P., Contreras, J. M., Cañadas, G. R., \& Gea, M. M. (2017). Evaluación de la componente afectiva del conocimiento didáctico-matemático de futuros profesores sobre estadística. In J. M. Contreras, P. Arteaga, G. R. Cañadas, M. M. Gea, B. Giacomone, \& M. M. López-Martín (Eds.), Actas del Segundo Congreso International Virtual sobre el Enfoque Ontosemiótico del Conocimiento y la Instrucción Matemáticos. Disponible en enfoqueontosemiotico.ugr.es/civeos.html

Beltrán-Pellicer, P., \& Godino, J. D. (2017). Aplicación de indicadores de idoneidad afectiva en un proceso de enseñanza de probabilidad en educación secundaria. Perspectiva Educacional, 56(2), 92-116.

Blanco, L., Guerrero, E., \& Caballero, A.(2013).Cognition and affect in mathematics problem solving with prospective teachers. Mathemacs Enthusiast, 10(1/2),335-364.

Breda, A., Font, V. \& Lima, V. M. R. (2015). A noção de idoneidade didática e seu uso na formação de professores de matemática. Jornal Internacional de Estudos em Educação Matemática, 8(2), 1-41.

Dawson, A. J., Jaworski, B., \& Wood, T. (Eds.). (2003). Mathematics teacher education: Critical international perspectives. Dordecht: Routledge.

Engel, J. (2019). Statistical literacy and society. In J. M. Contreras, M. M. Gea, M. M. López- Martín, \& E. Molina-Portillo (Eds.), Actas del Tercer Congreso International Virtual de Educación Estadística. Disponible en www.ugr.es/local/fqm126/civeest. html

Estepa, A. (2008). Interpretación de los diagramas de dispersión por estudiantes de bachillerato. Enseñanza de las Ciencias, 26(2), 257-270.

Estrada, A., Batanero, C., \& Lancaster, S. (2011). Teachers' attitudes towards statistics. In C. Batanero, G. Burrill, \& C. Reading (Eds.).Teaching statistics in school mathematicsChallenges for teaching and teacher education (pp.163-174). Springer, Dordrecht.

Franklin, C., Kader. G., Mewborn, D., Moreno, J., Peck, R., Perry, M. y Scheaffer, R. (2007). Guidelines for assessment and instruction in statistics education (GAISE) report: A Pre-K-12 curriculum framework. Alexandria, VA: American Statistical Association. Online: www.amstat.org/Education/gaise/.

Gea, M. M., Batanero, C., Arteaga, P., \& Estepa, A. (2019). La componente cognitiva del conocimiento didáctico-matemático de profesores en formación sobre correlación y regresión. Caminhos da Educação Matemática, 9(2), 79-101. 
Gil, N., Blanco, L. J., \& Guerrero, E. (2005). El dominio afectivo en el aprendizaje de las matemáticas. Una revisión de sus indicatores básicos. Unión, 2(1), 15-32.

Godino, J. D. (2013). Indicadores de la idoneidad didáctica de procesos de enseñanza y aprendizaje de las matemáticas. Cuadernos de Investigación y Formación en Educación Matemática, 11(1), 111-132.

Godino, J. D., Batanero, C., Rivas, H., \& Arteaga, P. (2013). Componentes e indicadores de idoneidad de programas de formación de profesores en didáctica de las matemáticas Revemat, 8(1), 46-74.

Godino, J. D., Giacomone, B., Batanero, C., \&Font, V. (2017). Enfoque ontosemiótico de los conocimientos y competencias del profesor de matemáticas. Boletim de Educação Matemática, 31(57), 90-113.

Godino, J. D., Rivas, H., Arteaga, P., Lasa, A., \&Wilhelmi, M. R. (2014). Ingeniería didáctica basada en el enfoque ontológico-semiótico del conocimiento y la instrucción matemáticos. Recherches en Didactique des Mathématiques, 34(2), 167-200.

Goldin, G., Hannula, M., Heyd, E., Jansen, A., Kaasila, R., Lutovac, S., \& Zhang, Q. (2016). Attitudes, beliefs, motivation and identity in mathematics education. ICME-13 Topical Surveys. New York: Springer. Google Scholar.

Gómez-Chacón, I. (2016). Métodos empíricos para la determinación de estructuras de cognición y afecto en matemáticas. En A. Berciano et al. (Eds.). Investigación en Educación Matemática XX (pp.93-114). Malaga: Sociedad Española de Investigación en Educación Matemática.

Gómez-Chacón, I. M. (2000). Affective influences in the knowledge of mathematics. Educational Studies in Mathematics, 43(2),149-168.

Guzmán, M. (2003). Los goces estéticos del quehacer matemático. Revista de la Real Academia de Ciencias Exactas, Físicas y Naturales 97(3), 351-457.

Hannula, M. S. (2002). Attitude towards mathematics: Emotions, expectations and values. Educational Studies in Mathematics, 49(1), 25-46.

Hill, H. C., Ball, D. L., \& Schilling, S. G. (2008). Unpacking pedagogical content knowledge: Conceptualizing and measuring teachers' topic-specific knowledge of students. Journal for Research in Mathematics Education, 39(2), 372-400.

Holmes, P. (1997). Assessing project work by external examiners. In I. Gal, \& J. B. Garfield (Eds.), The assesment challenge in statistics education (pp.153-164). Voorburg: IOS Press. Llinares, S. (2018). Mathematics teacher's knowledge, knowledge-based reasoning, and contexts. Journal of Mathematics Teacher Education, 21(1), 1-3.

Kislenko, K. (2009). Mathematics is a bit difficult but you need it a lot: Estonian pupils' beliefs about Mathematics. In J. Maaß \& W. Schlöglmann (Eds.), Beliefs and attitudes in mathematics education: New research results (pp.143-163). Rotterdam: Sense Publishers.

Krippendorff, K. (2013). Content analysis: an introduction to its methodology. London, Sage.

Llinares, S. (2018). Mathematics teacher's knowledge, knowledge-based reasoning, and contexts. Journal of Mathematics Teacher Education, 21(1), 1-3.

MacGillivray, H., \& Pereira Mendoza, L. (2011). Teaching statistical thinking through investigative projects. En C. Batanero, G. Burrill, \& C. Reading, (Eds.), Teaching statistics 
in school mathematics. Challenges for teaching and teacher education. A joint ICMI and IASE study (pp.109-120). New York: Springer Pino-Fan, L. R., \& Godino, J. D. (2015). Perpectiva ampliada del conocimiento didáctico-matemático del profesor. Paradigma, 36(1), 87-109.

MECD, Ministerio de Educación, Cultura y Deporte (2015). Real Decreto 1105/2014, de 26 de diciembre, por el que se establece el currículo básico de la Educación Secundaria Obligatoria y del Bachillerato. Madrid: Autor.

Pfannkuch, M., \& Wild, C. (2004). Towards an understanding of statistical thinking. In D. Ben-Zvi \& J. B. Garfield (Eds.), The challenge of developing statistical literacy, reasoning and thinking (pp.17-46). Dordrecht: Kluwer.

Pierce. R., \& Chick, J. (2011). Teachers' beliefs about statistics education. En C. Batanero, G. Burrill, \& C. Reading, (Eds.), Teaching statistics in school mathematics. Challenges for teaching and teacher education. A joint ICMI and IASE study (pp.151-162). New York: Springer.

Ridgway, J. (2015). Implications of the data revolution for statistics education. International Statistical Review. DOI: 10.1111/insr.12110.

Souza, L. D., Lopes, C. E., \& Pfannkuch, M. (2015). Collaborative professional development for statistics teaching: a case study of two middle-school mathematics teachers. Statistics Education Research Journal, 14(1), 112-134.

Tishkovskaya, S., \& Lancaster, G. (2012). Statistical education in the 21 st century: a Review of challenges, teaching innovations and strategies for reform. Journal of Statistics Education, 20(2), 1-24.

Veloo, A., \& Chairhany, S. (2013). Fostering students' attitudes and achievement in probability using teams-games-tournaments. Procedia-Social and Behavioral Sciences, 93, 59-64. 